\title{
What Information Do Citizens Want? Evidence from One Million Information Requests in Mexico
}

\author{
Forthcoming, World Development
}

Daniel Berliner (corresponding author)

Assistant Professor of Political Science and Public Policy, London School of Economics

D.Berliner@lse.ac.uk

Benjamin E. Bagozzi

Assistant Professor of Political Science and International Relations, University of Delaware

bagozzib@udel.edu

Brian Palmer-Rubin

Assistant Professor of Political Science, Marquette University

brian.palmer-rubin@marquette.edu

\begin{abstract}
While scholars have emphasized the importance of information for accountability, little research has addressed the demand for government information by real citizens. We study the totality of information requests filed with Mexican federal government agencies from 2003 to 2015, over 1 million requests in all. We use unsupervised methods to categorize requests, revealing the diversity of topics including environment, security, budgets, and government procurement and employees. While many topics have clear public accountability-seeking purposes, others are focused on more private, micro-political goals. Analysis over time and across states reveals linkage between information demand and issues of public interest such as environmental impacts and criminal violence. Our results demonstrate that, given functioning access-to-information institutions, citizens in a transitional democracy really do demand information relevant to public accountability.
\end{abstract}




\section{Introduction}

Citizens around the world are more empowered to seek and access government information than ever. Over 100 countries have passed access-to-information (ATI) laws, enabling citizens to request documents and information and obligating officials to respond (Ackerman and SandovalBallesteros 2006, Roberts 2006, Florini 2007). National, provincial, and local governments around the world are also embracing new "open government" mechanisms, making government information available proactively through online platforms (Meijer et al. 2012, Fung 2013, Piotrowski 2016). Research on the supply of government information is advancing on multiple fronts, seeking both to understand why and how such policies and mechanisms come about, and what effects information has on citizen and politician behavior.

However, little attention has been paid to the demand for information. Most research to date has relied on implicit assumptions about what information citizens actually want. Research and advocacy on ATI and open data policies are motivated by the assumption that they function as a tool of public accountability - but are these policies being used that way in practice? And experimental research that exposes citizens in developing countries to informational treatments generally fails to ask what politically relevant information those citizens might actually want, and actually seek on their own in a real-world context. We thus focus on main two questions: What information do citizens seek? And how does information demand link to issues of public importance?

When provided with a mechanism to request government information, do citizens ask for documents or data that they can use to hold policymakers publicly accountable - that is, to evaluate government performance, investigate potential wrongdoing, or mobilize for political 
goals? More broadly, can the information sought by citizens contribute to "action cycles" (Fung et al. 2007; Kosack and Fung 2014) that help engender public accountability?

Past approaches suggest two different models, differing in the extent to which citizens ${ }^{1}$ predominantly seek information with public or private goals. Under a public accountability model of information demand, citizens seek information that is suitable to uses in political mobilization and oversight, and is linked with issues of importance or interest to the population at large. Such a model is also consistent with traditional principal-agent approaches to electoral politics. Activists, journalists, and electoral campaigns have much to gain by obtaining evidence of government performance and decisionmaking, particularly in low- and middle-income democracies where corruption and inefficiency are widespread (Rothstein 2011), and many case studies offer success stories of information use in campaigns to demand better public services or denounce corruption (e.g. Jenkins and Goetz 1999, Cejudo 2012, Gaventa and McGee 2013, van Zyl 2014). These cases present the tantalizing possibility that the demand for public accountability-generating information is the rule rather than the exception, and that the main obstacle in most contexts is not demand but supply: the availability of functioning ATI institutions.

However, many skeptics see publicly-relevant information as only the "tip of the iceberg," with more mundane information comprising the submerged majority (Michener and Worthy 2015). Under such an "iceberg” model, citizens predominantly seek information for private, micro-political goals with little potential for publicity or demand-making on behalf of

\footnotetext{
${ }^{1}$ By "citizens" we mean the entire public; including ordinary individuals as well as organizations, journalists, and commercial entities that may be acting either on their own account or as intermediaries in disseminating information to the broader public.
} 
collective goals, and unlinked from issues of public attention. Examples include information useful in solving private problems, either in the business sector (e.g., navigating regulations, pursuing government contracts) or for individuals (e.g. accessing government benefits, completing official procedures, acquiring data for research). While these uses are important, they resemble the sorts of information most often available on government websites (Thomas and Streib 2003, Almazan and Gil-García 2008), and may not justify costly investments in ATI institutions. Some critics, often politicians themselves, even argue that ATI institutions are being abused through such private uses, constituting a waste of government resources (Kwoka 2016, Worthy 2017).

Further cause for skepticism derives from recent experimental studies that have found only mixed or inconclusive results as to whether exposure to new information can change voter behavior or spark greater accountability (e.g. Humphreys and Weinstein 2012, Lieberman et al. 2014, Chong et al 2015). These studies raise the possibility that the supply of information is not the core obstacle to holding politicians accountable, but rather deficits in human capital and collective action capacity are to blame. Such deficiencies may affect not only what people do with information, but also their demand for accountability-relevant information in the first place. Further, classic studies linking socioeconomic status to political participation (Verba et al. 1978; Verba et al. 1995) suggest that demand for publicly relevant information would be more anemic in new democracies, where a greater share of citizens are poor and inexperienced in democratic politics.

By studying the demand for information by real citizens, we evaluate the validity of these two models. We find evidence that both public, macro-political and private, micro-political uses are frequent and persistent over time. However, we find that the majority of topics of information 
demand have clear potential for public accountability-oriented uses, and that demand for information is linked to issues of public importance both over space and over time. These findings support the public accountability model of information demand, amended with a recognition of the complex layering of multiple information uses, both public and private, even on the same platform and from the same government agencies.

We assess citizen demand for information in the context of Mexico, using data on every information request filed with federal government agencies from 2003 to 2015 - over 1 million in all. Mexico's Ley Federal de Transparencia y Acceso a la Información Pública Gubernamental (Federal Law on Transparency and Access to Public Information) was signed into law by President Vicente Fox on June 10, 2002. This law has been called "one of the world's most innovative and best funded, operational and responsive" (Michener 2015), and "an unprecedented opportunity to address the rising public demand for a government committed to transparency, accountability, and respect for a citizen's right to know" (Sobel et al. 2006, 6).

We take an inductive approach to characterizing Mexico's ATI environment, using unsupervised topic modeling to categorize all 1 million-plus requests into twenty topics, based on the text of the requests themselves. These include many topics of clear public relevance, including the military, police, and crime; the oil and energy sectors; budgets and spending; the environment and land use; qualifications of government employees; and compliance information about public procurement. Other topics, however, appear more suited to private or micropolitical uses, such as seeking access to government benefits, services, or contracts. We characterize these topics and provide additional detail on each in an Online Appendix.

We also demonstrate a strong linkage between demand for information and issues of public salience that vary across space - such as oil production - and over time - such as the 
prevalence of criminal violence. These findings suggest that demand for government information is indeed embedded in processes of public accountability. Given the opportunity to use transparency mechanisms with relatively low barriers and relatively high performance, citizens in Mexico really do demand a diverse variety of information relevant to public accountability. The case of Mexico is of both theoretical and practical importance. While Mexico underwent a democratic transition in 2000, corruption and patronage remain commonplace, making it a frequent focus of studies on information and political accountability (Berliner and Erlich 2015, Chong et al. 2015, Fox 2007, Larreguy et al. 2016). A pioneer among transitional democracies in the sophistication of its ATI institutions, we take Mexico as a test case to address whether citizens in such contexts actually seek accountability-producing information when provided with the opportunity. In practical terms, Mexico's ATI law offers the opportunity to study the usage of a transparency mechanism in totality, over an extended period of time. In creating an online information system as the default means of filing requests, Mexico was unique among countries until recently. We build on the public availability of these data, including both request texts and metadata such as date, target agency, and locality.

Importantly, our focus is limited to observed information requests. Our analysis is not of information demand by average citizens, or a representative sample of all citizens, but rather of the demand for information by those who sought government information. Like studies of many forms of political engagement - such as protest and campaign contributions - we observe only those who actually engage. Our analysis is thus not representative of what information all citizens would seek, were they to request. However, our focus on "revealed" demand is not only representative, but in fact exhaustive, of the information sought by citizens whose desire for 
information outweighs the transaction costs of making requests. Thus, our approach is conducive to inferring the real-world uses of government information for public or private purposes.

\section{The Supply and Demand for Government Information}

ATI institutions are tools for vertical accountability (Mainwaring and Welna 2003, O'Donnell 1998), designed to make politicians "answerable" (Schedler 1999) to citizens. Their premise is that when citizens have access to information about government performance and decisionmaking, their political participation - both at the ballot box and through coordinated mobilization or lobbying - becomes more effective. There is thus a substantial focus on studying the supply of information - both in explaining the adoption and implementation of transparency institutions (Alt et al. 2006, Berliner 2014, Wehner and De Renzio 2013, Schnell 2017, Lagunes and Pocasangre 2017, Wood and Lewis 2017) as well as the effects of information on political institutions and outcomes (Besley and Burgess 2001, Alt and Lassen 2006, Snyder and Strömberg 2010, Worthy et al. 2017).

More recently, a substantial literature has sought to test the effects of information supply using experimental approaches. Researchers deliver informational treatments to citizens, gauging their effect on public goods and service provision (Peisakhin and Pinto 2010, Reinikka and Svensson 2011, Lieberman et al. 2014), corruption (Olken 2007), or voting behavior (Chong et al. 2015, Humphreys and Weinstein 2012). Findings from many of these studies have been mixed or inconclusive. Some propose conditions that mediate the effect of information, such as individuals' political attitudes and skills (Lieberman et al. 2014) or communities' collectiveaction capacity (Fox 2015). 
But these studies fail to address an even more fundamental threat to informational theories of accountability: Do citizens really seek information about government performance in their political activities? Most applications of the principal-agent model to political accountability (Ferejohn 1986, Przeworski et al. 1999, Besley and Burgess 2001) implicitly require not just that citizens respond to information when supplied, but also that they demand information necessary to evaluate government performance. Yet this piece of the puzzle has received little explicit scholarly attention, perhaps because it is less amenable to conventional causal hypothesis testing. Better understanding of how information operates as a tool of accountability requires answering descriptive questions on the nature of demand, in addition to testing causal arguments about the effects of supply.

To this end, our study places the focus on citizens, interrogating the demand-side of ATI. We ask: when given the opportunity to request government information, what type of information do citizens actually ask for? Citizen demand for information is pivotal in ATI systems such as Mexico's where information comes in response to citizen requests to government agencies. Indeed Fung (2013) describes such systems as "information on demand."2

\footnotetext{
${ }^{2}$ This ATI model contrasts with "targeted transparency," where government agencies (or private actors) are compelled through mandatory disclosure to produce "standardized, comparable, and disaggregated information...to further a defined social purpose" (Fung, et al. 2007: 6). A third paradigm of transparency, which has received increasing attention, is "open government," wherein governments proactively provide datasets that citizen groups analyze, often using sophisticated computational methods. While these two paradigms certainly have characteristics that are preferable to the information-on-demand model, our focus on the latter allows us to address the most prevalent mode of information delivery. As a practical
} 
We analyze citizen behavior in the context of a well-functioning ATI system, ${ }^{3}$ assessing the extent to which citizens request the type of information that is potentially useful in generating public accountability. We focus on what Joshi and Houtzager (2012: 151) refer to as social accountability: "ensuring the implementation of existing state obligations." This definition stresses the oversight role of citizens and civil society in 1) evaluating government performance, particularly as it relates to the provision of services and public goods; and 2) detecting and exposing corruption. We consider a certain unit of information (a document, dataset, or datum) as relevant to public accountability if it is potentially useful in media coverage, political campaigns, the activation of horizontal accountability institutions (e.g. judiciary or anticorruption), or in public participation oriented towards demanding that politicians make policy changes or answer for their actions. This aligns with Michener and Worthy's (2015: 10) distinction between public information - "pertinent to a broad, general audience" - and private uses "whose primary objective is self-regarding interest of an individual or particular group."4

matter, by analyzing a request-based ATI system, we are availed with systematic data about the information that citizens request.

${ }^{3}$ While far from perfect, Mexico's ATI system is high performing relative to most in both developing and developed countries (Michener 2015). On average roughly 100,000 requests have been filed annually in recent years, and a majority receive on-time and positive responses. Although as Fox et al. (2011) reveal, a substantial portion of responses labeled as positive do not satisfactorily provide the information requested.

${ }^{4}$ Michener and Worthy (2015) also distinguish between political and non-political types of information, but conclude that even nominally non-political uses tend to still have political implications, so we focus on their public-private distinction. 
Existing research on information demand offers two contrasting expectations, which we group into an optimistic "public accountability model" and a more pessimistic "iceberg model."

On the one hand, scholars of ATI both around the world (Banisar 2006, Florini 2007) and in Mexico (Hevia 2012, Isunza Vera 2006, López Ayllón 2006) are quite optimistic about the theoretical potential of information to spur civic engagement and government accountability. Empirical studies of information demand in Mexico often analyze success cases, confirming these theorized benefits (Cejudo 2012, Fox et al. 2007, van Zyl 2014). ${ }^{5}$ Assessments in India suggest that many citizens seek information "with the aim of redressing grievances about the failure to deliver public services or complete public works," with some examples of uses by advocacy groups and anti-corruption campaigns (Roberts 2010). Distelhorst (2017) demonstrates that, even in a non-democratic context with weak ATI institutions, activists in China are able to use information requests as a tool for political mobilization. For these scholars, information fills in a missing link, adding content to the demands of activists eager and willing to deploy it to pressure the state.

Other studies - though also not based on systematic or representative data - have been considerably less sanguine about the accountability-enhancing effects of information. Scholars have suggested that while politically relevant requests receive the most attention among media and activists, these may be the "tip of the iceberg," whereas the "submerged" mass of requests

\footnotetext{
${ }^{5}$ Other research in Mexico seeks to evaluate and score the quality of laws and formal institutions that constitute the ATI infrastructure, both nationally and subnationally (IFAI 2012, López Ayllón et al. 2013, Peschard, et al 2013, Trinidad Zaldívar 2006). Further studies evaluate government responsiveness, either by scoring the quality of government responses to actual information requests (Doyle 2008, Fox et al.
} 2011) or using a "simulated user" approach (Cejudo et al. 2017, Lagunes and Pocasangre 2017). 
are mundane, apolitical, or private (Michener and Worthy 2015). Studies in Pakistan and Bangladesh found requests "primarily to address personal grievances" or "personal matters such as bank loans and school examination results" (Asia Foundation 2014, p. 20-21), while a study in Albania reported "almost 90 percent of the requests are for basic information like access to drugs or medicine, procedures to get diploma accreditation, and deadlines for application for the universities" (Dokeniya 2013, p. 56). ${ }^{6}$

These more sobering findings lend credence to depictions from the electoral behavior literature of citizens as information misers (Kitschelt 2000, Lupia 1994, Redlawsk 2004). More critical views, such as Fenster $(2015,161)$, even suggest that the public may be "uninterested, distracted, or incapable or unwilling to consider the revealed state." Perhaps detailed information about government performance is simply not an important tool in electoral campaigns or activism, and citizens base their engagement on personal experience, news coverage, and elite cues. Alternatively, information may be useful, yet actual demand is restrained by limited human capital or financial resources - variables shown to shape civic engagement more broadly (Verba et al. 1995) - such that only elite and particularistic interests actually seek government information. Such limitations may be particularly relevant in lower-income and new democracies, such as Mexico - the very countries that suffer the most from poor governance.

\footnotetext{
${ }^{6}$ Doubts about ATI's potential for accountability outside the developing world have also been raised. A frequent criticism of the United States Freedom of Information Act is its preponderant use by commercial entities for private purposes (Piotrowski 2008; Kwoka 2016), while in the United Kingdom, Worthy and Hazell (2016) note that requests by members of the public (as opposed to journalists, businesses, or researchers) "generally involve matters of private interest rather than wider political issues, focusing on specialized local or personal issues - waste, street fixing, tax and permits.”
} 
In order to evaluate these two models, we analyze several traits of actual citizen demand for information in Mexico. Do citizens primarily seek information useful in holding politicians accountable to their policy promises and good governance; or for their own private goals? Is the ATI system broadly used across policy areas or is it rather an enclave for a few topics or agencies? Is demand sensitive to changing features of public interest over space and time? This is the first independent study, to our knowledge, that conducts a systematic analysis of all citizen requests in a given context. ${ }^{7}$ As scholars increasingly emphasize the importance of "usercentered" information environments (Fung et al. 2007, Jaeger and Bertot 2010), it is essential to understand how citizens actually use ATI institutions.

\section{Data and Methods}

Sample and Preprocessing

Our project examines citizen demand for information by using unsupervised text analysis to categorize information requests by Mexican citizens. This method allows us to characterize the content of a large number of requests, moving beyond anecdotal depictions from high-profile cases. We complement the topic modeling approach with our own qualitative interpretations of the information categories in which we infer the accountability-generating potential of topics.

Specifically, we analyze all ATI requests made to the federal Mexican government during the 2003-2015 period. Beginning with the launch of Mexico's electronic request system

\footnotetext{
${ }^{7}$ Mexico's information commission has conducted smaller-scale analysis of citizen requests (see: http://inicio.inai.org.mx/SitePages/Transparencia-Proactiva-acciones.aspx), hand-coding roughly 100-300 requests for each of several government agencies, and developing an emergent coding scheme for the types of information sought, such as statistics, contracts, procedures, and documents.
} 
in June of 2003, every federal ATI request has been made publicly available in CSV format on the government's INFOMEX website, along with a range of associated metadata (INAI 2015). We downloaded each of these files for the 06/2003-08/2015 period, ${ }^{8}$ which contain the texts of each request, links to any associated attachments, and other relevant metadata including target agency, date, requester municipality, and date and nature of official response. However, these data include no information on the actual users, their identities or demographics, or which requests were filed by the same user. The annual number of public information requests, among full years of the data, ranged from 34,702 in 2004 to a peak of 116,615 in $2014 .{ }^{9}$ This increase in request volume itself suggests that citizens see value in the institution.

Here we briefly describe how the request texts were formatted into a set of documents for topic modeling analysis. We provide a more extensive discussion of the preprocessing steps in the Online Appendix. The texts are citizens' own open-ended descriptions of the information requested, as entered into the INFOMEX system, for all public information requests. ${ }^{10}$ While the

\footnotetext{
${ }^{8}$ At the time of analysis, the latest publicly available requests corresponded to 8/31/2015.

${ }_{9}^{9}$ This is equivalent to just under one request per 1,000 population in recent years. Comparisons by Holsen and Pasquier (2012) and Michener (2015), although including both information requests and personal data requests, suggest requests per population in 2010 were higher in Mexico than in Canada, the United Kingdom, and India; but lower than in some Latin American countries with smaller populations such as Chile, El Salvador, and Peru.

${ }^{10}$ In addition to public information requests, the INFOMEX system also allows citizens to request personal data or corrections to personal data, such as employment records or social security entitlements. We do not include such personal data requests in this analysis, as they are governed by a different legal regime, and have their texts redacted from publicly available data for privacy reasons.
} 
majority of requesters entered requests in a primary text field, a subset either left this field blank, or in 128,695 cases (just over $10 \%$ of the total) included a portion, or their entire request, as an attached file. We webscraped these attachments and converted each to machine-readable text. ${ }^{11}$ Finally, we merged these converted files, along with an optional secondary text field, into our primary request text field. As a small number of requests were extremely long, often where an attached file contained an example report or a large spreadsheet, we truncated any request over 1,000 character strings. This affected only $0.02 \%$ of our final documents.

For all remaining request texts, we applied a set of common natural language processing techniques to convert our final corpus into a collection of individual "documents" compatible with the unsupervised topic modeling techniques used below, and to correct common typos, remove stopwords, and remove the most infrequently used words. These preprocessing steps are described in detail in the Online Appendix, and are generally consistent with similar preprocessing efforts applied to political texts (Roberts et al. 2014; Bagozzi 2015; Bagozzi and Berliner 2016). These tasks yielded a corpus with 1,023,267 processed request documents and 6,696 unique words.

\section{Modeling Approach}

We characterize the content of ATI requests using an unsupervised topic modeling approach known as Latent Dirichlet Allocation (LDA; Blei et al. 2003). ${ }^{12}$ LDA is a probabilistic topic model that uncovers latent dimensions of texts. These latent dimensions, or "topics," are

\footnotetext{
${ }^{11}$ A very small number $(<0.1 \%$ of all attachments $)$ were corrupted or missing, so not converted.

${ }^{12}$ We describe this method in greater detail in our Online Appendix, alongside our rationale for choosing LDA over other plausible topic models.
} 
assumed to have a representative set of words, and each document is then assumed to contain multiple overlapping topics. LDA then discovers these topics via a three-level hierarchical Bayesian model that treats documents as finite mixtures of underlying topics, and topics as infinite mixtures over a corresponding latent set of topic probabilities (Blei et al. 2003, 993). In this manner, each topic can be characterized by the set of words that LDA estimates as having the highest probability of association with that topic.

As with most topic models, the researcher must choose the number of topics, $k$, to be estimated within LDA. We agree with others (e.g., Roberts et al. 2014) that there is no "right" choice for $k$, and that this decision should primarily rest on substantive expertise and the granularity of interest. Nevertheless, measures of topical density have proven useful for topic number selection in past LDA-research, and we apply these diagnostic tools in full in the Online Appendix. Stated briefly, we find that an optimal number of topics for our corpus lies in the $k=$ $[20,50]$ interval. To guard against overfitting, we follow extant applications (e.g., Barberá et al. 2014, Bagozzi 2015), as well as the one standard error rule (Hastie et al. 2009), to determine that $k=20$ is optimal for our application.

We also estimate LDA models across a range of different topic numbers, and qualitatively evaluate their output. This comparison is presented in the Online Appendix, and again strongly suggests that our corpus can be most intuitively represented by a 20-topic model. Thus, both our model fit analysis and qualitative assessments provide support for the choice of a 20-topic LDA model for our primary analysis, to which we now turn.

\section{Topics}


We estimate our primary 20 topic LDA model on our full corpus of 1,023,267 preprocessed documents via Gibbs sampling. ${ }^{13}$ This model identifies the 20 topics that best characterize the request texts across the 2003-2015 period. Each topic represents an underlying word distribution where every word in the corpus is given a probability of assignment to that topic. For these word vectors, we first derive the 10 "topwords" assigned the highest probability of association with each topic based on posterior word distributions. We next derive the 10 topwords that are both most highly associated with a given topic and most exclusive ("FREX") in their assignment to a given topic, according to frequency exclusivity scoring metrics (Roberts et al. 2014). These word assignments inform our substantive interpretations of each topic.

We also classified each document according to its single most associated topic. Using the probability estimates of each document's association with each topic, we identified the topic with the highest probability of association for each document, and classified documents accordingly. This approach has precedent in text analysis literatures (Blei et al. 2003:1014, Bagozzi 2015, Wilkerson and Casas 2017; Hagemann et al. 2017), and summary statistics reported in the Online Appendix indicate that the typical request exhibits one topic with a "dominant" probability of assignment.

We discuss our procedure for interpreting and labeling each topic in the next section. We report these labels, along with each topic's topwords, in Figures 1 and 2 below. Note that our original topword vectors contained stemmed Spanish words. In order to present the topwords in a more interpretable manner, we identify the most common unstemmed version of each (stemmed) topword within the original corpus, and then translate each of these unstemmed topwords to English. We present these English-translated versions of each topic's 10 topwords - alongside

\footnotetext{
${ }^{13}$ See the Online Appendix for further discussion of modeling choices.
} 
our final topic labels - in Figure 2. We present the equivalent for the most frequent and exclusive words in Figure 3. We also present original Spanish-language versions in the Online Appendix. Additionally, we show the variation over time in the prevalence of each topic. The plots in Figure 3 show the trend over time for each selected topic (in black), and all other topics (in grey - for scale), as a proportion of all requesting activity. Thus, if requests in a given topic remain relatively flat over time as a proportion of all requests, that still reflects a growing absolute number of requests, as total request volume rises over time. 


\begin{tabular}{|c|c|c|}
\hline Topic & Top 10 Words & Labels \\
\hline 1 & mexican; request for bids; josé; general; director; neighborhood; borough; copy; neighborhood; luis & Employees 3: Personnel \\
\hline 2 & credit; fiscal; payment; administration; federal; date; public; bank; tax; treasury & Taxes and Finance \\
\hline 3 & municipality; located; zone; project; water; request; buildings; san; environmental; federal & Environment and Land \\
\hline 4 & work; request; year; personal; wage; social; security; salary; payment; base & Employees 1: Salaries/Benefits \\
\hline 5 & public; administration; name; addresses; general; area; employees; organization; officials; job & Employees 2: Functions/Qualif. \\
\hline 6 & to know; information; can; thank you; to do; case; services; some; existence; should & Individual Needs \\
\hline 7 & each; month; code; existing; inventory; box; health; basic; entered; final & Medical 3: Inventories \\
\hline 8 & request; copy; documents; date; information; request/application; number; purpose; register; certified & Commercial Information \\
\hline 9 & program; project; development; national; support; social; carry out; resources; which; actions & Distributive Programs \\
\hline 10 & request; approved; assembly; insertions; information; public; mexican; acts; corruption; following & Procurement 3: Anti-Corruption \\
\hline 11 & i request; documents; borough; imss; delivery; provider; code; request for bids; institute; goods & Medical 1: Contracts/Suppliers \\
\hline 12 & pemex; mexican; services; year; business; operation; type; electronic; transportation; production & Energy and Utilities \\
\hline 13 & medication; year; number; hospital; i request; health; special; age; information; national & Health Statistics \\
\hline 15 & education; studies; school; level; higher education; university; course; academic; technology; national & Education \\
\hline 16 & how much; year; number; i request; information; personal; which; federal; date; case & Military, Police, and Crime \\
\hline 17 & how much; year; budget; expenses; amount; each; destination; i request; information; part & Budgets and Spending \\
\hline 18 & contract; services; firm; amount; i request; name; dependents/employees; request for bis; date; security & Procurement 1: Service Providers \\
\hline 19 & request for bids; services; contract; technical personnel; public; decision; aquisitions; proposal; procedure; statement & Procurement 2: Procedures/Docs \\
\hline 20 & purchase; please; number; information; medication; price; descriptions; amount of money; current; products & Medical 2: Purchases/Spending \\
\hline
\end{tabular}

Figure 1: Ten highest probability words representing each topic. Based on the original Spanishlanguage word-stems, these are first unstemmed then translated into English.

\begin{tabular}{|c|c|c|}
\hline Topic & Top 10 Words & Labels \\
\hline 1 & perez; huasteca; ortiz; vargas; javier; castro; first; hector; muñoz; aguilar & Employees 3: Personnel \\
\hline 2 & credit; tribunal; ficrea; bank; trial; bank; condusef; saving; financial; contributors & Taxes and Finance \\
\hline 3 & ejido; property; plots of land; wage; forest; surface area; bureaucratic procedure; semarnat; mining; environmental & Environment and Land \\
\hline 4 & retirement; pensions; labor union; tabulator; wage; salary; work; perceptions; salary related; salary & Employees 1: Salaries/Benefits \\
\hline 5 & villagomez; organization; employees; international; officials; vacancies; officials; position; career/degree; job & Employees 2: Functions/Qualif. \\
\hline 6 & the; can; to do; wait; in advance; help; i want; to know; to resort to; i would like & Individual Needs \\
\hline 7 & tablets; patch; nicotine; acid; aspirin; paracetemol; acetaminophen; centimeters; chewable; dissolvable & Medical 3: Inventories \\
\hline 8 & single; certified; purpose; file; copy; file; permission; file; health; lottery & Commercial Information \\
\hline 9 & strategy; program; rural; indigenous; development; prevention; promotion; meters; populations; cooperation & Distributive Programs \\
\hline 10 & corrupt; anticorruption; mxsincorruptos; honesty; twitter; we will honor; contact us; [email address]; remember; bullets & Procurement 3: Anti-Corruption \\
\hline 11 & brushes; distromed; berrones; endotracheal; sterile; catheter; replacement; dental; round; holiday & Medical 1: Contracts/Suppliers \\
\hline 12 & lighting; expense; price/rate; energy; diesel; pemex; cfe; telecommunications; refining; exportation & Energy and Utilities \\
\hline 13 & patients; hospital related; prescriptions; mortality; hospital; treatment; sex; illnesses; medication & Health Statistics \\
\hline 15 & students; professors; staff; school; education; teacher; university; bachelor's degree; women; master's degree & Education \\
\hline 16 & police; detained; confiscated; military/soldier; drug trafficking; victims; crimes; migratory; crime; roberto & Military, Police, and Crime \\
\hline 17 & expenses; travel; travel allowance; budget; destination; donations; library; president; money; advertising & Budgets and Spending \\
\hline 18 & federal budget; benefit; maneuver; freight; contract; celebrated; policy; package; firm; formalized & Procurement 1: Service Providers \\
\hline 19 & roof; different; proposal; decision; proposal; statement; opening; leds; glossary; aquisitions & Procurement 2: Procedures/Docs \\
\hline 20 & medication; purchase; to carry out; differentiating; price; restricted; storage; address; paragraph; sold & Medical 2: Purchases/Spending \\
\hline
\end{tabular}

Figure 2: Ten most "frequent and exclusive" words representing each topic (Roberts et al. 2014). Based on the original Spanish-language word-stems, these are first unstemmed then translated into English. 


\section{Topics of Information Demand}

Our topic modeling approach was quite successful at identifying distinct and internally coherent topics of information request, and our analysis of these topics offers evidence that Mexico's ATI system serves as a platform for citizens to access a wide variety of government information. We first discuss the inductive process by which we labeled each topic and evaluated its relevance to public accountability. We then offer greater detail on five topics - Environment and Land; Individual Needs; Budgets and Spending; Commercial Information; and Military, Police, and Crime - reflecting the diversity of both public and private information demands. (The Online Appendix provides extensive discussion of all twenty topics and our method for labeling each.)

Our substantive interpretations of each topic are based on close readings of 1,600 total requests (corresponding to 80 sampled information requests from each topic), lists of each topic's 20 topwords and "FREX" topwords, the distribution of requests across agencies, and the distribution of requests across states. To interpret each topic and assess likely requesters and potential action cycles, we triangulate across these multiple sources of information, as well as interviews conducted in several government ministries, media coverage of ATI requests, and our substantive familiarity with politics, civil society, and ATI in Mexico. While we do not know definitive attributes of each requester, we highlight the types of requesters most likely to make use of each topic of information. Table 1 shows our qualitative coding for the potential of each topic to generate accountability as well as several other key characteristics. 


\begin{tabular}{|c|c|c|c|c|c|}
\hline $\begin{array}{l}\text { Topic } \\
\text { No. }\end{array}$ & Topic Label & $\begin{array}{c}\text { \% of } \\
\text { Requests }\end{array}$ & Common Request Types & Potential Requesters/Action Cycles & $\begin{array}{l}\text { Potential for } \\
\text { Accountability }\end{array}$ \\
\hline 3 & Land and the Environment & 8.64 & $\begin{array}{l}\text { Environmental impact } \\
\text { reports; construction permits; } \\
\text { land titles; infrastructure } \\
\text { plans }\end{array}$ & $\begin{array}{l}\text {-Citizen groups: protest or legal mobilization for environmental } \\
\text { protection } \\
\text {-Journalists: investigating corruption and improper procedures } \\
\text {-Landowners and developers: title and permit procedures, } \\
\text { commercial information }\end{array}$ & high \\
\hline 6 & Individual Needs & 8.5 & $\begin{array}{l}\text { Information about accessing } \\
\text { gov. programs and benefits; } \\
\text { bureaucratic procedures }\end{array}$ & $\begin{array}{l}\text {-Citizens: researching how to access social benefits; guidance } \\
\text { for bureaucratic processes }\end{array}$ & low \\
\hline 17 & Budgets and Spending & 7.98 & $\begin{array}{l}\text { Aggregate budget figures; } \\
\text { specific budget items or } \\
\text { expense reports }\end{array}$ & $\begin{array}{l}\text {-Journalists: reporting on use of public funds } \\
\text {-Citizen groups: activism or lobbying to influence spending, } \\
\text { denounce corruption } \\
\text {-Researchers: obtaining data }\end{array}$ & high \\
\hline 8 & Commercial Information & 7.86 & $\begin{array}{l}\text { Intellectual property records, } \\
\text { business licenses, health and } \\
\text { safety inspection results }\end{array}$ & $\begin{array}{l}\text {-Firms: follow-up on regulatory processes; investigating } \\
\text { competitors; market research } \\
\text {-Watchdogs: researching chemical/medical product approvals }\end{array}$ & low/medium \\
\hline 9 & Distributive Programs & 7.06 & $\begin{array}{l}\text { Lists of beneficiaries, rules of } \\
\text { operation }\end{array}$ & $\begin{array}{l}\text {-Citizens: researching how to access gov. benefits } \\
\text {-Journalists/activists: investigating bias or patronage }\end{array}$ & high/medium \\
\hline 16 & Military, Police, and Crime & 6.84 & $\begin{array}{l}\text { Crime and criminal justice } \\
\text { statistics, security policies, } \\
\text { specific incidents }\end{array}$ & $\begin{array}{l}\text {-Journalists reporting on crime, violence, and security } \\
\text {-NGOs advocating for human rights and security policy } \\
\text {-Citizens: seeking information on violent events } \\
\text {-Researchers: obtaining data }\end{array}$ & high/medium \\
\hline 4 & $\begin{array}{l}\text { Government Employees 1: } \\
\text { Salaries and Benefits }\end{array}$ & 6.71 & $\begin{array}{l}\text { Wages and benefits of } \\
\text { government employees }\end{array}$ & $\begin{array}{l}\text {-Gov. employees (current and retired): seeking info. about } \\
\text { benefits, HR policy } \\
\text {-Citizens: seeking gov. employment }\end{array}$ & low \\
\hline 5 & $\begin{array}{l}\text { Government Employees 2: } \\
\text { Functions and } \\
\text { Qualifications }\end{array}$ & 6.26 & $\begin{array}{l}\text { Government employees } \\
\text { resumes, disciplinary records, } \\
\text { organizational charts }\end{array}$ & $\begin{array}{l}\text {-Citizens: seeking to contact gov. official; finding out who does } \\
\text { what; seeking gov. employment } \\
\text {-Journalists: investigating patronage hiring } \\
\text {-Gov. employees: info. about officials' qualifications }\end{array}$ & medium \\
\hline 12 & Energy and Public Utilities & 5.65 & $\begin{array}{l}\text { Statistics on } \\
\text { prices/investment/spending } \\
\text { of state oil company; prices } \\
\text { and infrastructure for utilities }\end{array}$ & $\begin{array}{l}\text {-Investors/contractors: seeking industry info. to guide proposals } \\
\text { or investment } \\
\text {-Journalists: investigating performance or corruption in PEMEX } \\
\text { and public utilities } \\
\text {-Academics/NGOs: eval. energy policy or service delivery }\end{array}$ & high/medium \\
\hline
\end{tabular}




\begin{tabular}{|c|c|c|c|c|c|}
\hline 14 & $\begin{array}{l}\text { Internal Procedures and } \\
\text { Official Documents }\end{array}$ & 5.19 & $\begin{array}{l}\text { Internal agency procedures; } \\
\text { specific document codes; } \\
\text { legislation and regulations }\end{array}$ & $\begin{array}{l}\text {-Firms: info. for public bids, regulatory processes } \\
\text {-Journalists: Seeking specific documents by reference number } \\
\text {-Gov. employees: seeking info. about hiring or HR practices } \\
\text {-Citizens or firms: seeking to identify relevant laws/regulations }\end{array}$ & low/medium \\
\hline 13 & Medical Statistics & 4.67 & $\begin{array}{l}\text { Aggregate statistics on } \\
\text { medical conditions and } \\
\text { treatments }\end{array}$ & $\begin{array}{l}\text {-Journalists: reporting on health statistics and medical services } \\
\text {-Academics/NGOs/Medical professionals: researching public } \\
\text { health and medical services }\end{array}$ & low \\
\hline 1 & $\begin{array}{l}\text { Government Employees 3: } \\
\text { Specific Personnel }\end{array}$ & 4.1 & $\begin{array}{l}\text { Internal HR records, asset } \\
\text { declarations, CVs }\end{array}$ & $\begin{array}{l}\text {-Journalists: reporting on gov. hiring practices, investigating } \\
\text { corruption or wrongdoing } \\
\text {-Citizens: seeking gov. employment }\end{array}$ & high \\
\hline 18 & $\begin{array}{l}\text { Public Procurement 1: } \\
\text { Service Providers }\end{array}$ & 4.09 & $\begin{array}{l}\text { Requests for bids (RFBs) or } \\
\text { contracts for consultants and } \\
\text { external contractors }\end{array}$ & $\begin{array}{l}\text {-Firms: seeking info. for gov. bids or following up on previous } \\
\text { bids } \\
\text {-Journalists/NGOs: oversight of contracting practices }\end{array}$ & medium \\
\hline 2 & $\begin{array}{l}\text { Banking, Finance, and } \\
\text { Taxes }\end{array}$ & 3.83 & $\begin{array}{l}\text { Records from financial crime } \\
\text { investigations; banking } \\
\text { oversight reports; tax data }\end{array}$ & $\begin{array}{l}\text {-Journalists/NGOs: reporting on financial policy or scandals } \\
\text {-Citizens: appeals for consumer financial protection }\end{array}$ & high \\
\hline 15 & Education & 3.66 & $\begin{array}{l}\text { School information and } \\
\text { performance, statistics and } \\
\text { names of teachers hired, } \\
\text { budgets for teachers' schools, } \\
\text { teachers' union }\end{array}$ & $\begin{array}{l}\text {-Journalists: reporting on education policy, hiring practices, } \\
\text { teachers' union } \\
\text {-Academics/NGOs: researching education policy } \\
\text {-Citizens: seeking employment; school information for children }\end{array}$ & high/medium \\
\hline 11 & $\begin{array}{l}\text { Medical Supplies 1: } \\
\text { Contracts and Suppliers }\end{array}$ & 2.82 & $\begin{array}{l}\text { Bids for medical supplies } \\
\text { provisioning, often with a } \\
\text { specific firm or RFB code }\end{array}$ & $\begin{array}{l}\text {-NGOs/citizen groups: investigating corruption, fraud, or under- } \\
\text { provision of medical services } \\
\text {-Firms: seeking info. for gov. bids or on previous bids }\end{array}$ & high \\
\hline 19 & $\begin{array}{l}\text { Public Procurement 2: } \\
\text { Procedures and Documents }\end{array}$ & 2.32 & $\begin{array}{l}\text { Specific procurement } \\
\text { documents: compliance } \\
\text { reports RFBs, procedures, } \\
\text { technical proposals, contracts }\end{array}$ & $\begin{array}{l}\text {-NGOs/citizen groups: researching procurement processes to } \\
\text { detect corruption } \\
\text {-Firms: seeking info. for gov. bids or following up on previous } \\
\text { bids }\end{array}$ & medium \\
\hline 10 & $\begin{array}{l}\text { Public Procurement 3: } \\
\text { Anti-Corruption Campaign }\end{array}$ & 2.03 & $\begin{array}{l}\text { Records of acquisition, } \\
\text { licensing for medical supplies } \\
\text { providers }\end{array}$ & $\begin{array}{l}\text { - Self-identified watchdog group investigating corruption and } \\
\text { under-provision in medical supplies }\end{array}$ & high \\
\hline 20 & $\begin{array}{l}\text { Medical Supplies 2: } \\
\text { Purchases and Spending }\end{array}$ & 1.24 & $\begin{array}{l}\text { Records of spending and } \\
\text { purchasing at public clinics }\end{array}$ & $\begin{array}{l}\text {-Firms: market research; seeking info. for gov. bids or following } \\
\text { up on previous bids } \\
\text {-NGOs/citizen groups: eval. procurement to detect corruption }\end{array}$ & medium \\
\hline 7 & $\begin{array}{l}\text { Medical Supplies 3: } \\
\text { Inventories }\end{array}$ & 0.56 & $\begin{array}{l}\text { Purchases and inventories of } \\
\text { medical supplies at public } \\
\text { clinics }\end{array}$ & -Firms: market research & low/medium \\
\hline
\end{tabular}

Table 1: Topics of information requests with descriptive information and accountability potential. Topics ordered by size. 


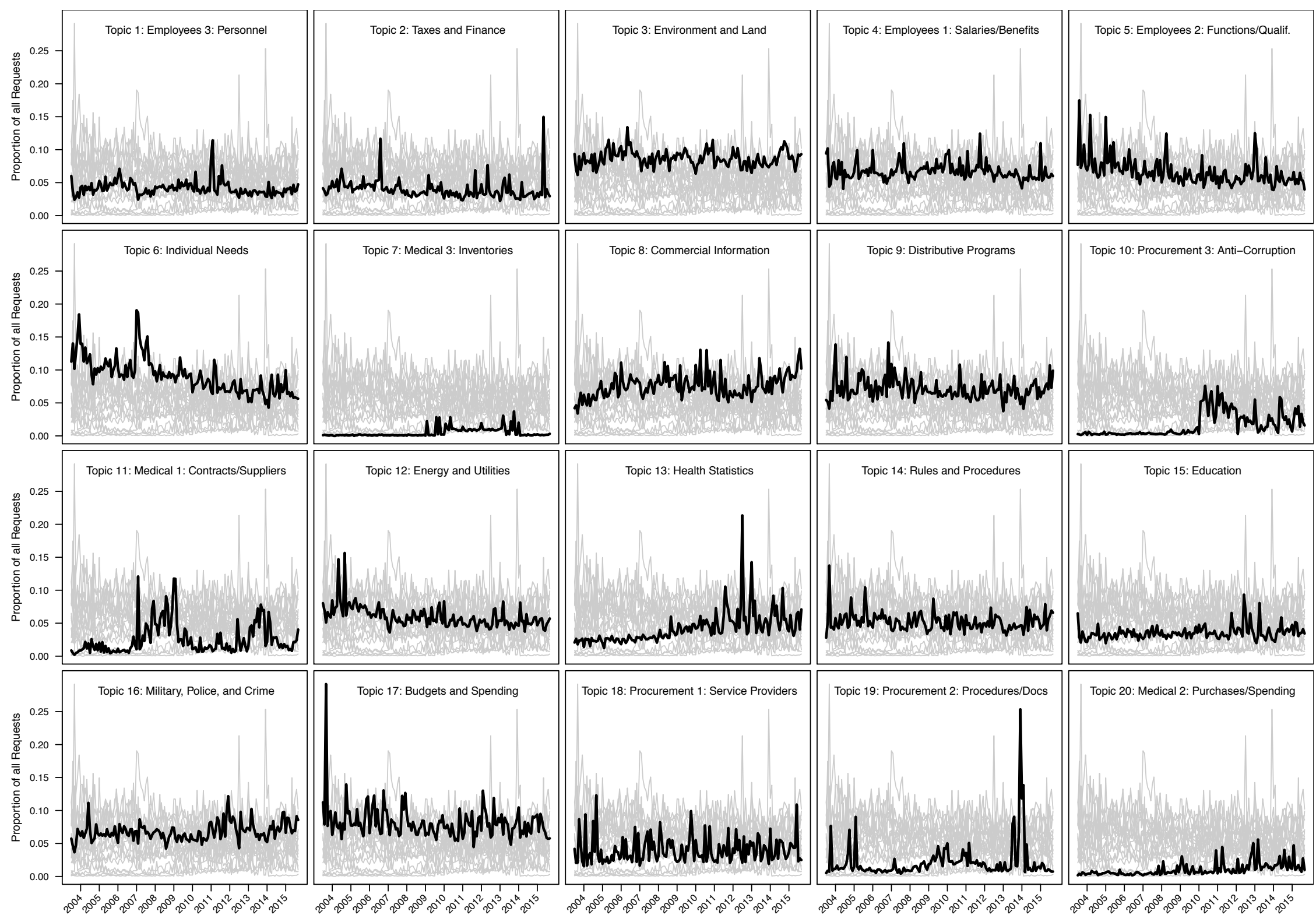

Figure 3: Trends over time for each topic's monthly proportion of all requests. Each topic is shown in black, with remaining topics in grey. 
In evaluating each topic's potential for accountability, we infer the potential requesters and their likely uses. As mentioned above, we understand public accountability-relevant information as that which is useful in evaluating government performance, decisionmaking, or detecting malfeasance. Thus, topics that we score as high are useful for such ends as monitoring provision of goods or services, investigating potential wrongdoing, or questioning official versions of events. Topics scored as less relevant include information that serves solely private purposes such as applying for government benefits, winning a government contract, or checking on a regulatory evaluation. While some topics include a mix of requests that appear to be accountability-generating and private, requests of each type nonetheless tend to cluster in different topics as illustrated in the in-depth discussions below. Topics coded as "high" were those for which the majority of reviewed requests (roughly 90 percent or higher) were clearly linked to accountability-seeking action cycles, while for topics in the "low" category this was much smaller (roughly ten percent or lower).

In Table 2, we present both the number of topics and the proportion of all requests falling into each of our categories of accountability-seeking potential. Notably, 52.6 percent of all requests pertain to topics with "Medium/High" or "High" potential for accountability, while 66.5 percent pertain to topics in the three highest categories.

\begin{tabular}{ccc} 
Potential for Accountability & Number of Topics & Percent of all Requests \\
\hline Low & 3 & 19.9 \\
Low/Medium & 3 & 13.6 \\
Medium & 4 & 13.9 \\
Medium/High & 4 & 23.2 \\
High & 6 & 29.4
\end{tabular}

Table 2. The number of topics, and associated percentage of requests, coded with each category of accountability-seeking potential. 
For the six topics coded as having high potential for accountability, the vast majority of requests reviewed were easily associated to accountability-seeking processes. These include some large topics, such as those on Environment and Land and Budgets and Spending (reviewed in detail below), as well as some smaller topics. For instance, Topic 10 consisted almost entirely of requests about medical procurement from a single anti-corruption campaign that frequently identified itself in requests.

We coded three topics as having low potential for accountability. It is difficult to envision how the information requested in these categories would be deployed for public purposes. Requests in Topics 6 (Individual Needs) and 4 (Government Employees: Salaries and Benefits) were closely connected to specific concerns of requesters themselves, in the former case because they were seeking guidance for accessing government benefits or resolving a particular bureaucratic process, and in the latter case because they were likely current, former, or prospective employees seeking information about pay scales, pensions, and benefits. Requests in Topic 13 (Medical Statistics) sought aggregate information about the incidence of diseases and treatment. While this information may be useful to academics or medical professionals, it does not provide the type of detailed information needed in evaluating policy performance or detecting corruption.

The eleven topics in middle categories were combinations of requests that appeared to be accountability-relevant with others of more likely private purpose. For instance, Topic 18, scored as having medium potential for accountability, has to do with public procurement, and many requests relate to the contracting of services for government agencies, such as internet service, consulting, or insurance. Civil society actors or journalists can make such requests to detect cronyism or kickbacks in the granting of these contracts. However, it is equally plausible that 
such requests are made by competing firms aiming to gain information for use in their own future bids.

What is clear from these topics, and their distributions, is that citizen demand for information comprises a wide diversity of uses. Citizens seek both accountability-relevant information and information for private uses. Even a single government agency is likely to receive a wide variety of information requests, potentially including beneficiaries seeking access to services or procedures, firms seeking contracts, academics seeking aggregate statistics, civic groups seeking information for activism, and journalists investigating spending, decisionmaking, or potential corruption.

We do not intend to denigrate private uses. The ability to seek information for private goals can help equalize otherwise-biased access to services. Offering a platform for citizen-state interaction can demonstrate government responsiveness regardless of the information being requested. Further, to the extent that the ATI system provides information about government regulatory procedures and contracts, it should favor healthy market competition. Nonetheless, such uses are inconsistent with those that motivated the ATI system's founding and may be better served through a proactive open-data system rather than a time-intensive request system.

The following sections describe several selected topics in greater detail. We devote particular attention to the four largest topics, as well as to the topic on Military, Police, and Crime - an issue of particular public salience. Full descriptions of all twenty topics, along with example requests and additional validity checks, appear in the Online Appendix.

\section{Topic 3: Environment and Land}


The largest topic, accounting for $8.6 \%$ of all requests, primarily concerns environmental issues, impact reports, construction, land tenure, and land use. This is reflected both in the topwords, and in the frequency of requests directed to ministries dealing with related matters. Many individual requests ask for environmental impact reports for specific projects, planning documents, property titles, boundaries of protected areas, or information on environmental damage. Likely requesters include both ordinary citizens and activists concerned about the environmental impact of development projects or disputes over land ownership. Indeed, officials at SEMARNAT, the environmental ministry, suggested that the most frequent type of information request they receive concerns local environmental conflict, frequently over the use and designation of protected land. ${ }^{14}$ Journalists may also seek such information, particularly given suspicion of corruption in projects violating proper permitting and environmental impact procedures.

As such, this topic has a high potential for accountability-seeking uses. Information may be deployed to make claims on the state regarding such public issues as environmental enforcement and infrastructure and such private claims as processing of land titles and permits. However, some requests may also come from developers or construction companies themselves, seeking information for commercial purposes.

One example of this type of information playing a role in public accountability comes from the case of a football stadium approved for construction in an ecological reserve on the outskirts of Monterrey, a large northern city. In 2012, two information requests to SEMARNAT, Mexico's environmental ministry, sought documents related to permitting and the environmental

\footnotetext{
${ }^{14}$ Interview, Mexico City, March 2017. Interviews conducted under Arizona State University IRB approval 00005773.
} 
impact report for the stadium. ${ }^{15}$ SEMARNAT ultimately denied the requests on the grounds that it was not their responsibility to provide the information, referring the requesters to municipal and state governments. However, upon appeal, the information commission found in favor of the requesters, arguing that SEMARNAT was obliged to produce documents in cases where land use rules were being altered for environmentally protected areas. Local environmental activists then used the information from the requested documents during a series of protests and media campaigns that lasted over two years, claiming that the company building the stadium had not followed proper procedures to change the land use category of the forest land to permit building a stadium. Although the stadium was ultimately completed, the movement managed to bring international scrutiny on the project and legal action against Heineken, an international partner of the Mexican corporation that owns the Monterrey-based soccer team and stadium.

\section{Topic 6: Individual Needs}

Requests in the second largest topic, accounting for $8.5 \%$ of all requests, are notable for their orientation towards individual needs, and most appear to be submitted by laypersons rather than elite actors. This is reflected in the topwords, which do not share a substantive theme but rather capture verbs such as "to do," "to know," and "would like," and other words frequent to simple

\footnotetext{
${ }^{15}$ On the information request and IFAI's upholding of the appeal for information to be released see: $<$ http://www.noticiasmvs.com/\#!/noticias/debera-semarnat-proporcionar-expedientes-de-lamanifestacion-de-impacto-ambiental-ifai-153>. On the activism against the stadium, see: $<$ http://horizontal.mx/el-estadio-bbva-bancomer-monumento-al-despojo-ambiental/ $>$ and $<$ http://www.proceso.com.mx/270051/viola-acuerdos-ambientales-el-proyecto-de-nuevo-estadio-demonterrey-firma-holandesa>.
} 
requests focused on the needs of the individual requester. Many requests in this topic ask how to access government services such as social benefits, pensions, education, or subsidized loans; or how to complete official procedures or fulfill requirements. Some of these requests ask where to go or inquire to fulfill these needs, while others ask what specific requirements, forms, or information is necessary. In interviews, officials from several different government ministries noted the frequency of requests with these characteristics.

This topic has very low potential for accountability-seeking purposes, as requests typically seek information useful for making private decisions or problem-solving, rather than information that may relate to state performance or malfeasance. This topic's share of all requests has also trended downward over time, possibly reflecting the increased availability of such information online.

A representative example is an information request submitted on January 17, 2007, in which the requester asked for information about how to apply for a government subsidized small-business loan for their bakery. Such requests do not fit into any typical link between information and accountability. The information requested will not provide evidence of government performance and is not plausibly useful to make politicians answerable to citizens.

\section{Topic 17: Budgets and Spending}

The third-largest topic, accounting for $8 \%$ of all requests, comprises requests concerning budgets and spending by government agencies. Most requests in this topic are clearly linked to accountability-generating action cycles. This is reflected in the topwords, and in the frequency of requests directed to the office of the President and the Ministry of Finance and Public Credit. Most individual requests in this topic ask for budget allocations or amounts of spending. Some 
ask for such information in aggregate terms (such as the full budget breakdown for a particular agency), while others are very specific (such as the amount spent for a particular use). Likely requesters include ordinary citizens, civil society groups, journalists, or even politicians or officials themselves - effectively anybody interested in budget or spending information but without alternative means to access it.

This topic clearly has a high potential for accountability-seeking uses, including attempts to identify improper or irregular spending, compare or criticize budget priorities, or identify corruption. In interviews, officials from several government ministries noted the frequency of receiving requests for information on spending, and suggested that such requests were often seen as the most likely to be politically sensitive or to generate negative media attention.

A frequent focus of these requests is agency spending on promotional campaigns, a common occurrence in Mexico where elected politicians and ministry heads buy advertising to promote government programs, public health campaigns, or other purposes. Such spending is often alleged of being misused to serve the electoral goals of politicians or to steer funds to allies. Several such requests were submitted by Fundar, a Mexico City-based NGO, as part of an oversight campaign seeking datasets and lists of ad buys and contracts between the government agencies and media firms themselves. ${ }^{16}$ Using these data, the campaign revealed that in the first year of Enrique Peña Nieto's presidency, the federal government exceeded by close to $50 \%$ the budget that had been approved by congress for official publicity, spending 7.6 billion pesos

\footnotetext{
${ }^{16}$ In addition to monitoring for overspending on publicity, these contracts permit detection into whether media companies offer special treatment to the ruling administration by undercharging.
} 
(about US $\$ 600$ million). ${ }^{17}$ Such findings helped pressure INAI to launch a new website in 2016, providing focused information on government advertising by local, state, and federal entities. ${ }^{18}$

\section{Topic 8: Commercial Information}

The fourth largest topic - accounting for $7.9 \%$ of requests - primarily concerns information of commercial relevance, such as trademarks, business licenses and registrations, product safety approvals, and administrative proceedings or court cases involving specific businesses or products. Most requests in this topic seek specific documents or statistics regarding commercial processes such as trademarks, product approvals, and business registrations. The vast majority of these betray a high level of expertise into government and business statutes and procedures, while requesting highly specific information that is unlikely to be of interest in accountability-generating action cycles. The two agencies that comprise the largest proportions of requests in this topic are COFEPRIS, which manages health and safety regulations for food and pharmaceutical products, and the Mexican Institute of Industrial Property, which manages patents and trademarks. This topic's share of all requests has generally trended upwards over time, potentially reflecting the extent to which commercial requesters are increasingly aware of information requests as a useful tool.

The most likely requesters in this topic are commercial entities seeking information on their own regulatory processes, or on those of their competitors or potential business partners. For instance, many requests to COFEPRIS referenced a case number and asked for specific dates

\footnotetext{
${ }^{17}$ See $<$ http://www.fundar.org.mx/mexico/pdf/LibertadDigitalOk.pdf $>$ (p. 61)

${ }^{18}<$ http://www.eluniversal.com.mx/articulo/nacion/politica/2016/11/23/ponen-lupa-gasto-del-gobiernoen-publicidad>
} 
and documents pertaining to product evaluations. Such usage parallels the situation in the United States and United Kingdom (Worthy 2013, Kwoka 2016), where commercial actors are among the most frequent ATI users, often filing requests to track their own regulatory approvals and those of their competitors. However, some requests in this topic may be accountability-seeking, particularly in cases of investigations into unsafe products or potential corruption in regulatory processes.

\section{Topic 16: Military, Police, and Crime}

This topic relates to the military and the criminal justice system. While the topwords by highest probability primarily pertain to classes of information - such as annual statistics and particular cases - the most frequent and exclusive words reflect an emphasis on police, the military, criminals, and drug trafficking. The agencies most frequently receiving requests in this topic are the Attorney General's Office, the Defense Ministry, the Ministry of Public Security, and the Federal Police.

This topic is the sixth largest, accounting for $6.8 \%$ of all requests. Its share of all requests remained relatively stable over time until roughly 2010, when it began to trend upwards (albeit with a dip in 2013), perhaps as a result of intensification of drug war-related violence.

Individual requests in this topic most often asked for aggregate statistics on crime, prosecutions, and violence, but several requests also related to security policies. Requests for statistics asked about the number of victims and number of prosecutions for specific crimes. Requests about security policies queried such topics as state treatment of human rights complaints or troop deployment in confrontations with organized crime. For instance, one request asked about the number of human rights victims registered by a human rights NGO that 
had been recognized as victims by the newly formed Executive Commission for Attention to Victims. This commission was created in 2013 at the pressure of social groups representing victims of human rights abuses related to Mexico's drug war and their families. ${ }^{19}$

Likely requesters of information about the military and security are journalists reporting on crime and the drug war, as well as NGOs that work with victims or local security. This topic has a high potential for accountability as such groups may use the information in campaigns to pressure the state to enhance security, redress victims, or to follow criminal law procedures. Information may be particularly relevant to electoral campaigns, as success and failings in the area of security are of high political salience, particularly in the context of scandals such as the 2014 disappearance of 43 students in the rural municipality of Ayotzinapa, which has been the focus of many information requests..$^{20}$

\section{Linkage of Information Demand to Issues of Public Salience}

Our examination of the topics of citizen demand for information suggest a wide diversity of uses, including both accountability-seeking and private purposes. To further evaluate the potential role of information in public accountability, we also assess the extent to which information demand exhibits linkage between changing real-world conditions and trends in information demand. Where the ATI system is used for accountability-seeking purposes, we would expect to find

\footnotetext{
${ }^{19}$ See: <http://expansion.mx/nacional/2012/04/25/la-ley-general-de-victimas-un-logro-mas-para-elmovimiento-por-la-paz>

${ }^{20}$ For example, $<$ http://www.proceso.com.mx/418730/el-expediente-ayotzinapa-una-burdamanipulacion $>$ and <http://eleconomista.com.mx/sociedad/2016/07/15/estudio-fuego-gasto-seguridadnacional $>$.
} 
strong linkage between information demand and changes over time and across regions in the issues that are likely to generate media attention, activism, and be most salient for citizen evaluation of government performance. Such linkage could take a variety of forms: Citizens and journalists may react directly to events and issues by seeking relevant information. Alternately, citizens and civic groups may react to media reports themselves by seeking additional information or mobilizing around new demands. Indeed, one government official noted a saying (translated) that "today's headline is tomorrow's information request." 21

We offer evidence of such linkage between variation in topics over space and time, and real-world issues of public interest such as the environment, oil production, and criminal violence. If citizens and organizations employ information requests in ways that engage with issues of public interest, and respond to new developments, then we should see the distribution of topics vary over space and time in correspondence with key issues.

Figure 4 maps the intensity of requests by state for four different topics. The Online Appendix contains maps for all twenty topics. These maps do not simply display the raw number of requests, as on that measure the Federal District predominates for nearly every topic. Rather, we calculate, for each topic and state, the share of all requests in a given state that is made up by a given topic. Thus, in the first panel of Figure 7, requests on Environment and Land make up a large proportion of requests filed from Baja California, even though a greater absolute number of requests on that topic are filed from the Federal District.

The spatial variation in these topics is consistent with an information request environment linked to issues of regional public salience. For instance, the distribution of request intensity for Topic 3 reflects greater interest in states where environmentally protected coastal areas have

\footnotetext{
${ }^{21}$ Interview, Mexico City, March 2017.
} 
been threatened by seaside tourist development. The distribution of request intensity for Topic 12 reflects that topic's focus on oil and energy production, with high request intensity in states with oil and natural gas production. For Topic 16, the spatial distribution of request intensity highlights northern states that have been sites of substantial violence during the Drug War, as well as Chiapas where both border issues and long-simmering rural conflicts have received substantial attention. Finally, requests on Topic 19, which emphasizes procedural information and documents related to public procurement, are focused in the Federal District and nearby states, with much less intensity of interest in the rest of the country. The fact that some topics of information demand are focused around the capital, while others are focused in different parts of the country, as well as the extent to which that variation corresponds with key issues of interest, demonstrates the linkage of information demand with issues of public salience. 

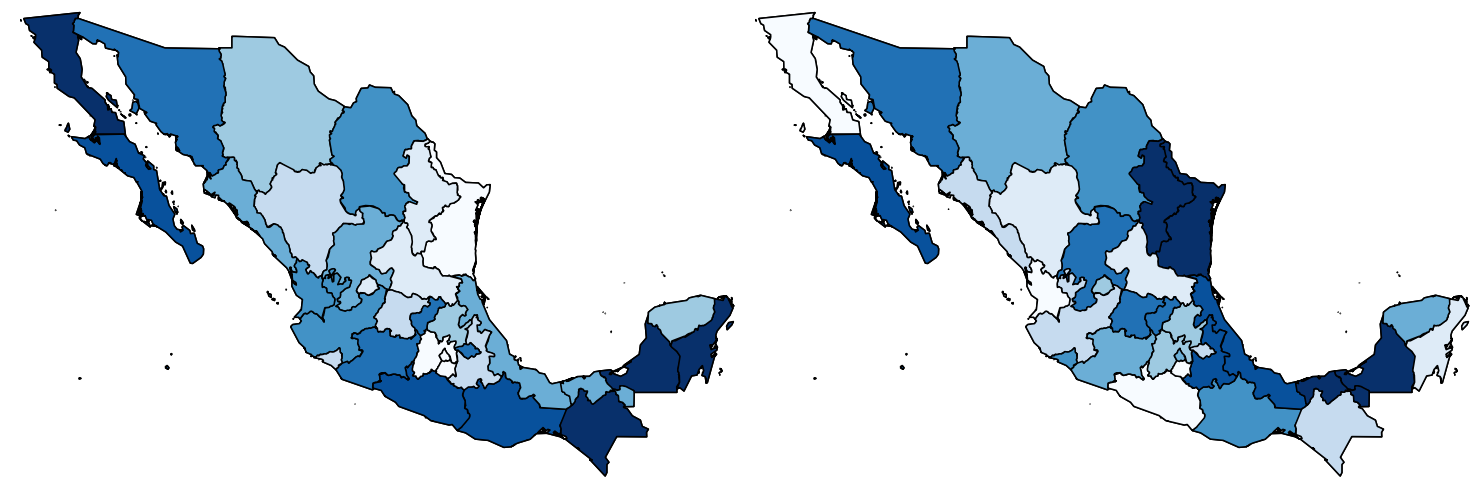

Topic 16: Military, Police, and Crime Share of Requests in Each State

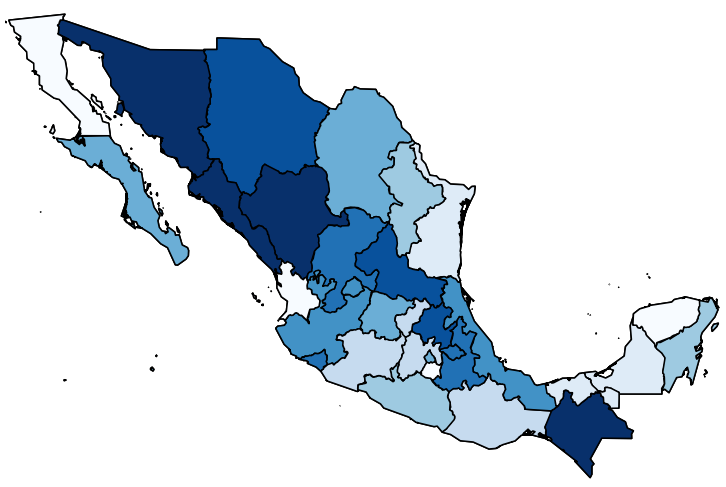

Topic 19: Public Procurement 2: Procedures and Documents Share of Requests in Each State

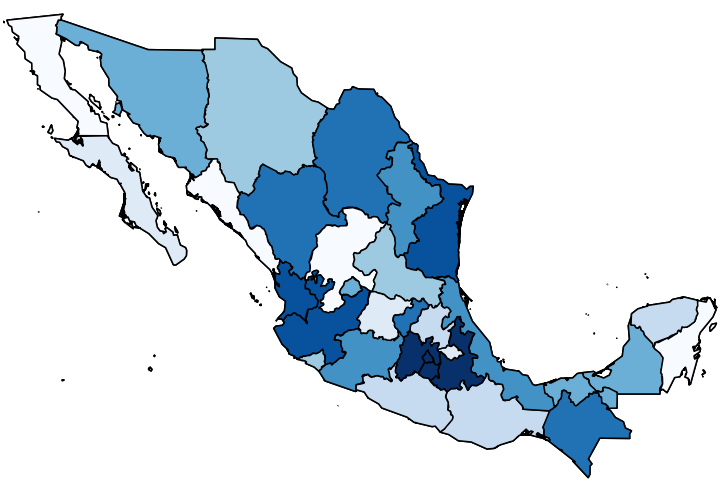

Figure 4: Request intensity by state for four different topics. States are shaded by the share of the specified topic out of all requests in that state. The scale is relative - the four states with the highest intensity for each topic are shaded the darkest color.

We also demonstrate linkage through the variation of information demand over time. We show that requests for information on Topic 16 (Military, Police, and Crime) are driven in part by actual levels of violence. We aggregate monthly counts of requests, and regress the logged number of requests associated with Topic 16 on the logged number of homicides across the country in the previous month, using data from INEGI. While not all of these homicides will be related to violent crime and drug-trafficking organizations of public interest, most of the 
systematic variation from month to month in aggregate homicide counts are likely to be driven by such developments. If citizens use information requests in a manner that is linked to shifts in issues of public interest, then we should see more homicides associated with more requests on the relevant topic of information.

Table 3 presents the results of five alternate models of the effects of monthly homicides on logged monthly information requests. Model 1 includes only the logged number of homicides in the previous month. Model 2 adds a lagged dependent variable, to account for serial dependence in the monthly number of requests related to the military, police, and crime. Model 3 adds month fixed effects, to account for seasonal trends (such as the tendency for fewer requests in December). All three of these models show a positive and statistically significant effect of homicides on requests for relevant information.

One concern might be that these results are simply driven by the overall differences between the periods before and after President Calderón escalated the "drug war" at the outset of his term in office. Model 4 thus demonstrates that the results still obtain, even employing only data from 2007 onwards. We also conduct a "placebo" test, using a dependent variable based on all requests for information, rather than Topic 16 only. Indeed, the effect of homicides on all requests for information is much smaller and only marginally significant, although still positive. This suggests that while the effect of homicides is primarily to increase the demand for information on the military, police, and crime, some other topics of information may also see increased demand as well. More broadly, these results suggest that citizen demand for government information is linked to real-world events of public interest, at least in the case of public violence. 


\begin{tabular}{|c|c|c|c|c|c|}
\hline & Model 1 & Model 2 & Model 3 & Model 4 & Model 5 \\
\hline Log Homicides $_{t-1}$ & $\begin{array}{c}0.734 * * * \\
(0.070)\end{array}$ & $\begin{array}{c}0.283 * * * \\
(0.077)\end{array}$ & $\begin{array}{c}0.176^{* * *} \\
(0.063)\end{array}$ & $\begin{array}{c}0.228^{* * *} \\
(0.060)\end{array}$ & $\begin{array}{l}0.087^{*} \\
(0.044)\end{array}$ \\
\hline Log Topic 16 Requests $_{t-1}$ & & $\begin{array}{c}0.613 * * * \\
(0.072)\end{array}$ & $\begin{array}{c}0.764 * * * \\
(0.062)\end{array}$ & $\begin{array}{c}0.152 \\
(0.115)\end{array}$ & \\
\hline $\log _{\text {All Requests }}$ R-1 & & & & & $\begin{array}{c}0.876^{* * * *} \\
(0.047)\end{array}$ \\
\hline Dependent Variable & Topic 16 & Topic 16 & Topic 16 & Topic 16 & $\begin{array}{c}\text { All } \\
\text { Requests }\end{array}$ \\
\hline $\begin{array}{l}\text { Time Period } \\
\text { Month Effects }\end{array}$ & $\begin{array}{l}\text { Full } \\
\text { No }\end{array}$ & $\begin{array}{l}\text { Full } \\
\text { No }\end{array}$ & $\begin{array}{l}\text { Full } \\
\text { Yes }\end{array}$ & $\begin{array}{c}2007+ \\
\text { Yes }\end{array}$ & $\begin{array}{l}\text { Full } \\
\text { Yes }\end{array}$ \\
\hline Adjusted $\mathrm{R}^{2}$ & 0.464 & 0.660 & 0.806 & 0.456 & 0.890 \\
\hline Number of Observations & 127 & 127 & 127 & 85 & 127 \\
\hline
\end{tabular}

${ }^{* * *} p<0.01,{ }^{* *} p<0.05,{ }^{*} p<0.10$ Standard errors in parentheses.

Table 3: Linear regression models of logged monthly requests filed in Topic 16: Military, Police, and Crime. Models 3-5 include month fixed effects, Model 4 omits the pre-2007 period from the sample, and Model 5 uses an alternative dependent variable of the logged number of all requests regardless of topic.

\section{Conclusion}

Recent scholarship has made important strides in empirically testing the conditions under which information about government performance translates into political accountability. Important findings regarding the types of information most conducive to accountability, and the types of users and environments most conducive to deploying this information effectively, promise to inform the future design of ATI institutions. Until now, however, we lacked a systematic analysis of the types of information that the public requests from governments when presented with an effective information-request system.

In this paper, we analyze the totality of information requests submitted to federal government agencies in Mexico from 2003 through 2015; over 1 million requests in all. As a means of sorting these into meaningful categories we use unsupervised topic models, a method designed to allow latent categories of information to emerge from bodies of text. Qualitative 
coding of the resulting twenty topics designates fourteen topics as medium or higher in their relevance to public accountability, on matters such as budgets and spending, public procurement, criminal violence, and environmental conflict. These fourteen topics comprise $66.5 \%$ of all requests ever filed. Although not every individual request within these topics is necessarily actively linked to accountability-generating processes -- just as not every request in the other topics is necessarily removed from such processes -- these results nonetheless make clear the strong preponderance of accountability-seeking potential across the twenty topics we identify. On the other hand, we also find substantial evidence of information requests for private uses, both for ordinary citizens seeking access to benefits and assistance with procedures and commercial users seeking information on government contracting and regulation.

We further assess the connection between citizen demand for information and issues of public relevance as they vary over both regions and time. We find evidence of such linkage, given suggestive geographic variation in topics pertaining to environmental issues, oil production, and public violence, as well as time-series models of request volume in relation to violence trends nationwide. The results suggest that a higher number of homicides is associated with more requests categorized in the topic on Military, Police, and Crime. More generally, these identified associations also suggest that future analyses of Mexico's ATI request texts may additionally benefit from more recent extensions to the LDA model that allow for the inclusion of document-level covariates as predictors of topical prevalence (e.g., Roberts et al. 2014)

Our evidence on the topics of information demand, and their linkage with topics of public importance over space and time, are consistent with a public accountability model of information demand. However, we cannot fully dismiss the relevance of private uses. We emphasize the diversity of information demand, and the complex layering of both types of uses, even on the 
same platform and from the same government agencies. Simply put, access-to-information systems are useful for a wide variety of objectives, and we demonstrate that the greater part of these are relevant to holding politicians accountable for efficient and honest governance.

Mexico may well represent a most-likely case to find citizen demand for accountabilityrelevant information. Among transitional democracies, Mexico was a leader in adopting a userfriendly information request system. Furthermore, as a society characterized by high levels of corruption and patronage, but also with a high density of civil society and interest organizations, there is no shortage of demand for information about what government does. Future studies may replicate our approach both in more mature democracies - which may more proactively provide information about government activities - and weaker democracies, where lack of state capacity or social capital may inhibit citizen demand for information.

In countries with relatively poor responsiveness such as Albania (Dokeniya 2013), Argentina (Michener 2015), or South Africa (Berliner 2017), citizens may find information requests a less worthwhile mechanism; whereas governments that more proactively release data about government performance may to some extent obviate the need for citizens to use these institutions for routine processes of political accountability (Holsen and Pasquier 2012). Yet on the other hand, the reverse may obtain as well: Proactively available information may enable more effective use of ATI requests, while limited compliance can even create new openings for mobilization (Distelhorst 2017).

Put together, our results suggest that citizens do, in fact, request information that is relevant to public accountability, when provided with the opportunity to do so. We thus offer a resounding affirmative response to the question "If you build it, will they come?" This suggests that, given a reasonably well-functioning ATI regime with low barriers to use, demand for 
information is not the key obstacle to successful information-based accountability. Nonetheless, the clear prevalence of organizations and journalists among the likely potential users of accountability-relevant requests also highlights the continuing importance of broader ecosystems of information intermediaries (Fung 2013) and interlocutors (Fox 2015).

However, we also highlight that these accountability-seeking uses exist alongside a substantial focus on information for private uses as well. Thus an important topic for future research is to explore whether accountability-seeking and private demands for government information tend to complement each other, or crowd each other out, in terms of the ability and willingness of officials to respond in positive ways. 


\section{Bibliography}

Ackerman, John, and Irma Sandoval-Ballesteros. 2006. "The global explosion of freedom of information laws." Administrative Law Review 58(1): 85-130.

Almazan, Rodrigo Sandoval, and J. Ramón Gil-García. 2008. "E-Government portals in Mexico.” In Electronic Government: Concepts, Methodologies, Tools, and Applications. Ari-Veikko Anttiroiko, Ed. IGI Global. 1726-1734.

Alt, James E., and Lassen, David Dreyer. 2006. “Transparency, political polarization, and political budget cycles in OECD countries.” American Journal of Political Science, 50(3), $530-550$.

Alt, James E., Lassen, David Dreyer, and Rose, Shanna. 2006. “The Causes of Fiscal Transparency: Evidence from the U.S. States.” IMF Staff Papers, 53, 30-57.

Bagozzi, Benjamin E. 2015. The multifaceted nature of global climate change negotiations. Review of International Organizations. 10(4): 439-464.

Bagozzi, Benjamin E., and Berliner, Daniel. 2016. "The Politics of Scrutiny in Human Rights Monitoring: Evidence from Structural Topic Models of US State Department Human Rights Reports." Political Science Research and Methods, Forthcoming. DOI: https://doi.org/10.1017/psrm.2016.44.

Banisar, David. 2006. "Freedom of Information Around the World 2006: A Global Survey of Access to Government Information Laws.” Privacy International.

Barberá, Pablo, Bonneau, Richard, Jost, John T., Nagler, Jonathan, and Tucker, Joshua. (2014). Is there anybody out there? The effects of legislators' communication with their constituents. Paper presented at ISA Annual Convention. 
Berliner, Daniel. 2014. "The political origins of transparency." The Journal of Politics, 76(2): 479-491.

Berliner, Daniel. 2017. "Sunlight or window dressing? Local government compliance with South Africa's promotion of access to information act." Governance 30(4): 641-661.

Berliner, Daniel, and Aaron Erlich. 2015. "Competing for transparency: Political competition and institutional reform in Mexican states." American Political Science Review 109(1): $110-128$.

Besley, Timothy, and Robin Burgess. 2001. "Political agency, government responsiveness and the role of the media." European Economic Review 45(4): 629-640.

Blei, David M., Ng, Andrew Y., and Jordan, Michael I. 2003. Latent dirichlet allocation. Journal of Machine Learning Research, 3:993-1022.

Cejudo, Guillermo M. 2012. "Evidence for change: The case of Subsidios al Campo in Mexico." International Budget Partnership Working Paper.

Cejudo, Guillermo M., et al. "Report de Resultados: Métrica de Gobierno Abierto 2017.” Centro de Investigación y Docencia Económicas and Institutional Nacional de Acceso a la Información.

Chong, Alberto, De La O, Ana L., Karlan, Dean, and Wantchekon, Leonard. 2015. “Does Corruption Information Inspire the Fight or Quash the Hope? A Field Experiment in Mexico on Voter Turnout, Choice, and Party Identification." Journal of Politics, 77(1), 5571.

Distelhorst, Greg. 2017. "The power of empty promises: Quasi-democratic institutions and activism in China." Comparative Political Studies 50(4): 464-498. 
Dokeniya, Anupama. 2013. Implementing the Right to Information: Lessons from Experience. Washington, DC: World Bank Group.

Doyle, Kate, Franzblau, Jesse, and Martínez-Morales, Emilene. 2008. "FOI in Practice: Analysis of the Mexican FOI System.” National Security Archive Electronic Briefing Book. 247. URL: http://www.gwu.edu/ nsarchiv/NSAEBB/NSAEBB247/index.htm.

Ferejohn, John. 1986. "Incumbent performance and electoral control." Public Choice 50(1): 525.

Fenster, Mark. 2015. "Transparency in search of a theory." European Journal of Social Theory. 18(2): 150-167.

Florini, Ann. 2007. The Right to Know: Transparency for an Open World. Columbia University Press.

Fox, Jonathan. 2007. Accountability politics: power and voice in rural Mexico. Oxford University Press.

Fox, Jonathan. 2015. "Social accountability: what does the evidence really say?" World Development 72: 346-361.

Fox, Jonathan, Libby Haight, Helena Hofbauer, and Tania Sánchez, eds. 2007. Mexico's rightto-know reforms: Civil society perspectives. Mexico City: FUNDAR/Woodrow Wilson International Center for Scholars.

Fox, Jonathan, Libby Haight, and Brian Palmer-Rubin. 2011. "Delivering Transparency: To What Degree Does the Mexican Government Respond to Public Information Requests?" Gestión y Política Públic 20(1): 3-61.

Fung, Archon. 2013. "Infotopia: Unleashing the Democratic Power of Transparency." Politics \& Society. 41(2): 183-212. 
Fung, Archon, Mary Graham, and David Weil. 2007. Full disclosure: The perils and promise of transparency. Cambridge University Press.

Gaventa, John and Rosemary McGee. 2013. "The Impact of Transparency and Accountability Initiatives." Development Policy Review. 31(s1): 3-28.

Hagemann, Sara, Sara B. Hobolt, and Christopher Wratil. 2017. "Government Responsiveness in the European Union: Evidence from Council Voting.” Comparative Political Studies. 50(6) $850-867$.

Hastie, T., Tibshirani, R., and Friedman, J. 2009. The Elements of Statistical Learning. Springer.

Hevia, Felipe. 2012. "Participación y transparencia. Estableciendo los vínculos.” In López Fernández, Iván ed. Transparencia focalizada a la contraloría social y rendición de cuentas. Xalapa, Mexico: Gobierno de Veracruz, pp. 111-40.

Holsen, Sarah, and Martial Pasquier. 2012. "What's wrong with this picture? The case of access to information requests in two continental federal states-Germany and Switzerland." Public Policy and Administration 27(4): 283-302.

Humphreys, Macartan, and Jeremy Weinstein. 2012. "Policing Politicians: Citizen Empowerment and Political Accountability in Uganda.” Working paper.

IFAI. 2012. Análisis del régimen de transparencia y acceso a la información en los estados y la federación. Mexico City: IFAI.

INAI. 2015. Sistema infomex gobierno federal. URL: https://www.infomex.org.mx/gobiernofederal/homeOpenData.action. Accessed on: $7 / 20 / 2015$.

Isunza Vera, Ernesto. 2006. "Para analizar los procesos de democratización: Interfaces socioestatales, proyectos políticos y rendición de cuentas.” In Isunza Vera, Ernesto and 
Alberto J. Olvera, eds. Democratización, rendición de cuentas y sociedad civil:

Participación ciudadana y control social. Mexico City: CIESAS, pp. 265-91.

Jaeger, Paul, and John Bertot. 2010. "Designing, implementing, and evaluating user-centered and citizen-centered e-government." International Journal of Electronic Government Research. 6(2): 1-17.

Jenkins, Rob, and Anne Marie Goetz. 1999. "Accounts and accountability: Theoretical implications of the right-to-information movement in India." Third World Quarterly. 20(3): 603-622.

Joshi, Anuradha, and Peter P. Houtzager. 2012. "Widgets or watchdogs? Conceptual explorations in social accountability." Public Management Review 14(2): 145-162.

Kitschelt, Herbert. 2000. "Linkages between citizens and politicians in democratic polities." Comparative Political Studies 33(6-7): 845-879.

Kosack, Stephen, and Archon Fung. 2014. “Does transparency improve governance?” Annual Review of Political Science. 17: 65-87.

Kwoka, Margaret. 2015. “FOIA, Inc.” Duke Law Journal, 65:1361-1437.

Lagunes, Paul, and Oscar M. Pocasangre. 2017. “Dynamic Transparency: An Audit of Mexico’s Freedom of Information Act.” Inter-American Development Bank Working Paper Series No. IDB-WP-836. URL: https://publications.iadb.org/handle/11319/8551.

Larreguy, Horacio A., John Marshall and James M. Snyder Jr. 2016. "Publicizing malfeasance: How local media facilitates electoral sanctioning of Mayors in Mexico.” Working paper. Lieberman, Evan S., Daniel N. Posner, and Lily L. Tsai. 2014. "Does information lead to more active citizenship?" World Development 60: 69-83.

López Ayllón, Sergio, ed. 2006. Democracia, transparencia y Constitución. Propuestas para un 
debate necesario. Mexico City: UNAM - Instituto Federal de Acceso a la Información Pública.

López Ayllón, Sergio, Mauricio Merino, and Lourdes Morales, eds. 2013. Hacia una política de rendición de cuentas en México. Mexico City: CIDE/Auditoría Superior de la Federación. Lupia, Arthur. 1994. "Shortcuts versus encyclopedias: Information and voting behavior in California insurance reform elections.” American Political Science Review 88(1): 63-76.

Mainwaring, Scott, and Christopher Welna, eds. 2003. Democratic Accountability in Latin America. Oxford: Oxford University Press.

Meijer, Albert, Deirdre Curtin, and Maarten Hillebrandt. 2012. "Open government: connecting vision and voice.” International Review of Administrative Sciences. 78(1): 10-29.

Michener, Gregory. 2015. “Assessing Freedom of Information in Latin America a Decade Later: Illuminating a Transparency Causal Mechanism." Latin American Politics and Society. 57(3): 77-99.

Michener, Gregory, and Benjamin Worthy. 2015. "The Information-Gathering Matrix A Framework for Conceptualizing the Use of Freedom of Information Laws." Administration $\&$ Society.

O’Donnell, Guillermo A. 1998. "Horizontal accountability in new democracies.” Journal of Democracy 9(3): 112-126.

Olken, Benjamin A. 2007. "Monitoring corruption: evidence from a field experiment in Indonesia." Journal of Political Economy 115(2): 200-249.

Peisakhin, Leonid, and Paul Pinto. 2010. "Is transparency an effective anti-corruption strategy? Evidence from a field experiment in India.” Regulation \& Governance 4(3): 261-280. Peschard, Jacqueline, et al. 2013. 10 Años de transparencia en México. Mexico City: IFAI. 
Piotrowski, Suzanne. 2008. Governmental transparency in the path of administrative reform. SUNY Press.

Piotrowski, Suzanne. 2016 “The 'Open Government Reform' Movement: The Case of the Open Government Partnership and US Transparency Policies." American Review of Public Administration.

Przeworski, Adam, Susan Stokes, and Bernard Manin. 1999. Democracy, Accountability, and Representation. Cambridge University Press.

Redlawsk, David P. 2004. "What voters do: Information search during election campaigns." Political Psychology 25(4): 595-610.

Reinikka, Ritva, and Svensson, Jakob. 2011. "The power of information in public services: Evidence from education in Uganda." Journal of Public Economics, 95(7-8), 956-966.

Roberts, Alasdair. 2006. Blacked out: Government secrecy in the information age. Cambridge University Press.

Roberts, Alasdair. 2010. “A Great and Revolutionary Law? The First Four Years of India’s Right to Information Act." Public Administration Review. 70: 925-933.

Roberts, Margaret E., Stewart, Brandon M., Tingley, Dustin, Lucas, Christopher, Leder-Luis, Jetson, Gadarian, Shana, Albertson, Bethany, and Rand, David. 2014. Structural topic models for open ended responses. American Journal of Political Science, 58(4):172-178.

Rothstein, Bo. 2011. The quality of government: Corruption, social trust, and inequality in international perspective. University of Chicago Press.

Schedler, Andreas. 1999. "Conceptualizing accountability." In The self-restraining state: Power and accountability in new democracies, Schedler, Andreas, Larry Diamond, and Marc F. Plattner, eds. Boulder: Lynne Rienner Publishers. 
Schnell, Sabina. 2017. "Cheap talk or incredible commitment? (Mis)calculating transparency and anti-corruption.” Governance. Forthcoming. https://doi.org/10.1111/gove.12298.

Snyder, J., and Strömberg, D. 2010. "Press coverage and political accountability.” Journal of Political Economy, 118(2): 355-408.

Sobel, David L, Bethany A. Davis Noll, Benjamin Fernandez Bogado, TCC Group, and Monroe E. Price. 2006. "The Federal Institute for Access to Public Information in Mexico and a Culture of Transparency." William and Flora Hewlett Foundation.

The Asia Foundation. 2014. Citizens' Access to Information in South Asia. Kathmandu, Nepal: The Asia Foundation.

Thomas, John Clayton, and Gregory Streib. 2003. "The New Face of Government: CitizenInitiated Contacts in the Era of E-Government." Journal of Public Administration Research and Theory. 13(1): 83-102.

Trinidad Zaldívar, Ángel. 2006. La transparencia y el acceso a la información como política pública y su impacto en la sociedad y el gobierno. Mexico City: Miguel Ángel Porrúa. van Zyl, Albert. 2014. "How civil society organizations close the gap between transparency and accountability." Governance 27(2): 347-56.

Verba, Sidney, Norman H. Nie, and Jae-on Kim. 1978. Participation and Political Equality: A Seven Nation Comparison. Cambridge: Cambridge University Press.

Verba, Sidney, Kay Lehman Schlozman, and Henry E. Brady. 1995. Voice and Equality: Civic Voluntarism and American Politics. Cambridge: Harvard University Press

Wehner, Joachim, and Paolo De Renzio. 2013. "Citizens, legislators, and executive disclosure: The political determinants of fiscal transparency." World Development. 41: 96-108. 
Wilkerson, John D. and Andreu Casas. 2017 “Large-Scale Computerized Text Analysis in Political Science: Opportunities and Challenges.” Annual Review of Political Science. 20. Wood, Abby, and David Lewis. 2017. “Agency Performance Challenges and Agency Politicization." Journal of Public Administration Research and Theory, 27(4): 581-595.

Worthy, Ben. 2013. “'Some are more open than others': Comparing the impact of the Freedom of Information Act 2000 on local and central government in the UK." Journal of Comparative Policy Analysis, 15(5): 395-414.

Worthy, Ben. 2017. The Politics of Freedom of Information: How and Why Governments Pass Laws that Threaten their Power. Manchester: Manchester University Press.

Worthy, Ben, and Robert Hazell. 2016. "Disruptive, Dynamic and Democratic? Ten Years of FOI in the UK." Parliamentary Affairs.

Worthy, Ben, Peter John, and Matia Vannoni. 2017. "Transparency at the Parish Pump: A Field Experiment to Measure the Effectiveness of Freedom of Information Requests in England." Journal of Public Administration Research and Theory. 27(3): 485-500. 